\title{
EXPLORATORY ANALYSIS OF THE EFFECT OF CONSULTANTS ON THE USE OF WORLD WIDE WEB SITES IN SMES
}

\author{
Sigi Goode \\ School of Business and Information Management \\ Australian National University \\ Canberra, Australia \\ Email: sigi.goode@anu.edu.au \\ Ph: +6126125 5048
}

\begin{abstract}
There is little published research on the role of consultants in technology adoption. Given the increasing popularity of the World Wide Web in commercial environments and the number of consultants now offering web development services, some analysis into the effects of their engagement would be of benefit.

In an extension of an ongoing study, an existing sample of 113 World Wide Web adopters was used to examine the nature of World Wide Web site use with respect to consultant and Internet Service Provider (ISP) engagement. Analysis was also conducted into the use of consultants and ISPs as developers and maintainers of these sites.

This preliminary research finds a number of interesting outcomes. No significant relationship is found between consultant or ISP engagement and World Wide Web site use, regardless of whether the consultant was engaged as site developer or site maintainer. The study raises a number of additional findings that are of interest but are not directly related to this study. These findings merit further research.
\end{abstract}

\section{INTRODUCTION}

There is considerable published evidence of the substantial growth in commercial WWW adoption over the past four years (Gallaugher 1999, Ranganathan and Ganapathy 2002). Several authors note the fervency with which companies are seeking to make efficient and cost effective use of this technology (Teo et al. 1997, Tan and Teo 1998, Liang and Lai 2002). The adoption of new technology, however, is not always smooth or successful. In some cases, the perceived difficulties of a new adoption, or the costs or risks of an unsuccessful adoption, are so great that some businesses may seek to supplement their existing abilities with those of an external consultant or consulting group (Rassam and Oates 1991). In particular, this may be the case where small business resource poverty means staff members must take on more than one role (Palvia and Palvia 1999).

This, combined with the relative newness of WWW research, makes fertile ground for a preliminary study into the area. At this early stage, with research into WWW adoption and success still largely in its infancy, this study is interested in the basic research question:

Does a company's engagement of consultants or ISPs affect that company's use of their WWW site?

This paper seeks to answer this question by comparing the site uses of businesses who have engaged consultants to those that have not. The rest of this paper is structured as follows: first, the paper examines the existing research into the use of technology consultants, and uses this analysis to derive some initial propositions for examination. The paper then examines the commercial uses of World Wide Web technology to determine the range of web technology applications with which a consultant may be able to provide assistance. The research method and sample are discussed, followed by hypothesis testing and discussion of results. Finally, limitations of the study are discussed and conclusions are made.

\section{CONSULTANTS AND INFORMATION SYSTEMS}

An examination of the Information Systems research literature reveals a lack of published research into the role of consultants in commercial information technology environments. Sturdy (1997) notes that the bulk of research in this area lies in the historical role of consultants in business, but argues that "little attention has been given to the wider...consequences of consultancy". Gable (1991), Soh et al. (1992) and Kole (1983) make similar arguments, observing the importance of studying the role of consultants in business, in particular with respect to small- and medium-sized organisations.

Existing research into the role of consultants in IT is thin, however the topic has received some scholarly attention, notably from Gable (1991). Gable argues that it is important to study consultants so as to be able to manage them more effectively, to justify further use or discontinuance of external consultants, to assess the impact of the engagement on the organisation, to assess the appropriateness of the level of client dependence on consultants, and to provide feedback to the client. Soh et al. (1992) note that the examination of the role of consultants in small business environments is important because small businesses are deficient in slack resources (or "resource poverty"), and may also lack technical support and/or experience. This lack of experience may also undermine the future of the firm, including developing a strategic plan (Dou and Dou 1999).

Soh et al. (1992) examine the topic of consultant engagement with respect to system success. The study found that consultant-engaging businesses had higher levels of computer usage. This, the authors argue, suggests that 
these businesses may have better operating procedures, and have better access to critical information. This conclusion would be consistent with Gable (1991) and Fitzgerald (1975). This leads to the first research proposition:

P1. Businesses that engage consultants will have higher levels of system use than businesses that do not.

Soh et al. also examined the level of business experience of firms that engage consultants. While their study found no significant differences in experience levels, Gable (1991), Major (1999), Sturdy (1997), Tisdall (1982) argue that consultants are often engaged in instances where system implementation staff or business operations are inexperienced or immature. Cavaye and Cragg (1995) conducted analyses of case businesses in six different industries and found that inexperienced businesses outsourced their implementation "so that their system was built by experienced professionals". This leads to the second research proposition:

$P 2$. Businesses that engage consultants have less experience with information systems than those that do not engage consultants.

It is important to note that the propositions made above are purely exploratory, intended to provide some initial assessment of the role of consultants in technology and website use. As such, the propositions are presented in the spirit of new research into an area. It is understood that there may be some degree of logical inconsistency between P1 and P2. Businesses with more IS experience for example, might have greater current system use (Bajaj and Nidumolu 1998). However, it is possible for a firm to have higher experience but less use: such would be the case for newer firms or new systems (Doll and Torkzadeh 1998), for instance. In this vein, exploratory research acknowledges that, for any phenomenon, there may be multiple objective points of view (Malhotra and Grover 1998). Such perspectives may exhibit differences, however each may be intrinsically valid (Walsham 1993) and is hence particularly useful in the early stages of research (Dubin 1978).

\section{THE WORLD WIDE WEB AND ITS COMMERCIAL USES}

The WWW is a technology that is receiving increasing attention in both the research literature and popular media. Businesses are apparently keen to adopt this new technology and its popularity as a marketing and information dissemination tool is increasing. While the technology can be easy to adopt and "unadopt", the process can be financially costly and/or time-consuming for businesses that are unfamiliar with the technology (Nambisan and Wang 1999). Businesses are faced with the choice of either self-tuition or the engagement of an external knowledge source such as a consultant or internet service provider (ISP).

A number of authors examine the business uses of World Wide Web technology. The literature suggests three broad uses, being the promotion of products and services, the provision of data and information, and the processing of business transactions. Table I details literature references to these uses.

Table I: Commercial Uses of the World Wide Web in the Research Literature

\begin{tabular}{|c|c|}
\hline Use/Application & Referencing Papers \\
\hline Promotion of Products and Services & $\begin{array}{l}\text { Swatman et al. (1995), Lin (1996), Lewis (1996), } \\
\text { Ravindran et al. (1996), Jarvenpaa and Todd (1997) Koreto } \\
\text { (1997) Haynes et al. (1998) Spiller and Lohse (1998) } \\
\text { Gallaugher (1999) Lindemann and Schmid (1999) }\end{array}$ \\
\hline Provision of Data and Information & $\begin{array}{l}\text { Swatman et al. (1995) Lin (1996) Abell and Lin (1996) } \\
\text { Jarvenpaa and Ives (1996) Liu et al. (1997) Haynes et al. } \\
\text { (1998) Spiller and Lohse (1998) Lindemann and Schmid } \\
\text { (1999) }\end{array}$ \\
\hline Processing of Business Transactions & $\begin{array}{l}\text { Swatman et al. (1995) Warkentin (1995) Bhimani (1996) } \\
\text { Panurach (1996) Feher and Towell (1997) Spiller and } \\
\text { Lohse (1998) Lee (1999) }\end{array}$ \\
\hline
\end{tabular}




\section{HYPOTHESIS DEVELOPMENT}

The propositions made above are now extended into testable hypotheses which relate the engagement of consultants to computer system and World Wide Web site use.

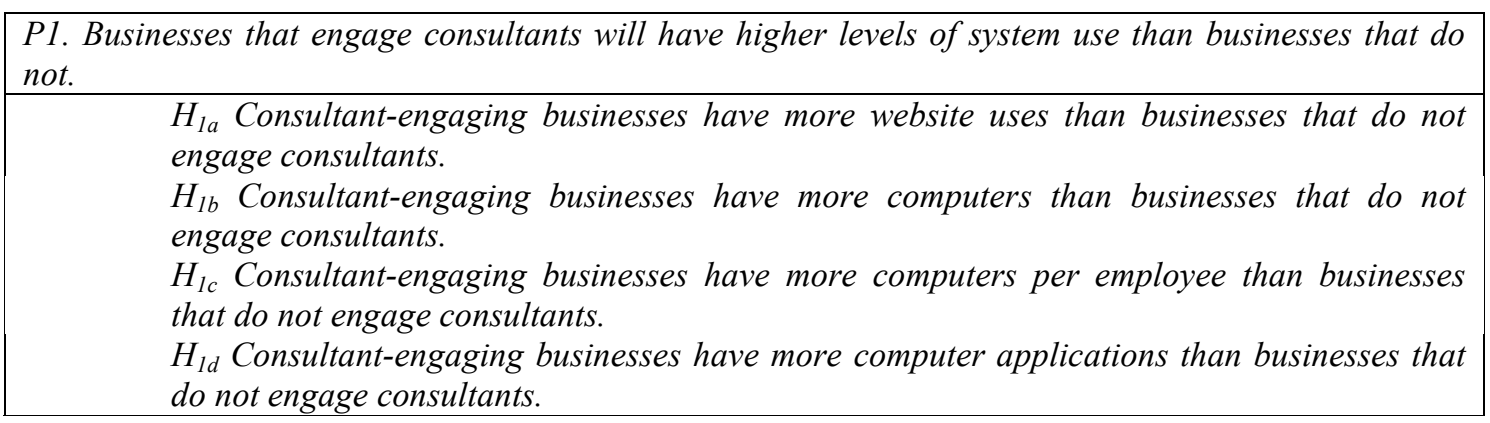

P2. Businesses that engage consultants have less experience with information systems than those that do not engage consultants.

$\mathrm{H}_{2 a}$ Consultant-engaging businesses have more years of computer use than businesses that do not engage consultants.

$H_{2 b}$ Consultant-engaging businesses have more years of web use than businesses that do not engage consultants.

\section{RESEARCH METHOD}

Data for this research were obtained from an ongoing study into the adoption of WWW technology. These data were originally obtained via a survey questionnaire of 245 Australian small businesses who were known adopters of WWW technology. The questionnaire instrument captured descriptive data on the business in addition to data concerning the business' adoption of the WWW. Questions regarding the identity of both the developer and the current maintainer of the website were included in the survey ${ }^{3}$. In addition, data were gathered concerning the business' use of the website. Where possible, questions were adapted from existing IS research, in particular Montazemi (1988) and Delone (1981). Space was included at the end of the question to allow the respondent to add site uses that may have been overlooked.

Once complete, the survey was pre-tested on a group of senior university staff, as advocated by Dillman (1978). This process proved useful in checking spelling and grammar in addition to survey structure and flow. After this pre-test, a pilot test was conducted using two local businesses. This second stage proved useful in restructuring the wording of two questions. Surveys were printed on paper bearing the official university letterhead and crest, and were accompanied by a letter assuring the respondents of confidentiality.

\section{THE SAMPLE}

The survey yielded a final useable response rate of 113 from 245 businesses targeted, yielding a response rate of $46 \%$. Analysis of respondent data was compared to population profiles provided by the Australian Bureau of Statistics (McLennan 1999): this analysis suggested a representative spread of businesses types, and showed that no businesses was unnaturally under or over represented in the respondent group.

Analysis of the existence of response bias was also conducted. As advocated by Grover et al (1994), data on business size and respondent position were examined with respect to early and later respondents. This analysis showed no significant differences. Filion (1975), however, notes that the determination of response bias may be error-prone. If the analysis of return dates provides an indication of response bias, the results shown in Table II would suggest that little bias, if any, exists. This is consistent with the high response rate obtained (Church 1993), which is substantially higher than normal response rates in the Information Systems research literature (O’Connor et al. 1997).

3 It was noted that there may be some biasing effect associated with the use of a consultant (perhaps some businesses may view consultant engagement as prestigious, for instance), so care was taken to structure the question in an open multi-selection format. Indeed, one respondent listed the site's developer simply as "daughter". 
Table II: Mann-Whitney Analysis of Response Differences

\begin{tabular}{|l|r|r|}
\hline & \multicolumn{1}{|c|}{ SIZE } & \multicolumn{1}{|c|}{ POSN } \\
\hline Mann-Whitney U & 1163.500 & 1632.000 \\
Wilcoxon W & 1829.500 & 2028.00 \\
Z & -1.377 & -.161 \\
Asymp. Sig. (2-tailed) & .168 & .872 \\
\hline
\end{tabular}

a. Grouping Variable: Date Received

Summary statistics for the respondent group are shown in Table III. Most businesses were in the Services sector, followed by Retail and Manufacturing. The majority of businesses employed less than ten staff members and were less than ten years old. These results suggest that most respondents were younger small businesses.

Table IV shows the respondent WWW usage summary statistics. Almost half of the respondents stated that their website was developed by an in-house person or group, the next largest source of site development being an external consultant. While many ISPs also now offer site design services, they made up the smallest group of site developers. These data on the use of in-house development methods support the "champion" theory whereby new technology is introduced into the firm by a single person who can spearhead its cause (Cavaye and Cragg 1995). The use of an in-house development group may provide advantages in terms of cost, and also may support good requirements communication in that all members of the development process are familiar with each other. Additionally, hiring a single person may require fewer resources than hiring a developmental team. The effect of this difference in resource requirement is unknown and, as a result, a distinction was made between these two groups.

Analysis of website maintenance data revealed an interesting trend. Most respondents were now using an inhouse person to maintain their websites: use of other methods of site maintenance had decreased. This evidence suggests that the initial adoption of the technology process may be the most challenging and technologically demanding phase of the adoption process. A significant number of respondents $(20 \%)$ still used the original consultants to maintain their website.

Most respondents used their site for the provision of company and product information. Almost half of all respondents used their website for the provision of online sales. Interestingly, only a small percentage kept pricing information on their site. These data suggest a discrepancy: only half of those sites who had used online sales mechanisms also featured prices on their site. Apart from simple respondent error, there may be several explanations for this. First, it is possible that the sales mechanisms used on these sites also incorporated prices into their operation, hence there was no need to store price information elsewhere. Second, it is possible that the products being sold were featured on a "price on application" basis (this would be consistent with the fact that most respondents were based in the service industry, where engagements may be priced on a case by case basis). No respondents supplied other uses for their website, which suggests that the uses provided in the survey were generally comprehensive. The provision of company information received the greatest use from respondents, supporting the contention that the WWW is used by many businesses at this stage as an alternative advertising medium. 
Table III: Business Summary Statistics

\begin{tabular}{|l|l|c|}
\hline Demographic & & \% \\
\hline Industry & Services & 49.7 \\
& Retail & 30.1 \\
& Manufacturing & 20.9 \\
\hline Number of & $0-5$ & 59.2 \\
Employees & $6-10$ & 17.6 \\
& $11-15$ & 8.8 \\
& $16-30$ & 6.8 \\
Age of Business & 31 or more & 7.2 \\
& 6- 5 years & 38.9 \\
& $11-15$ years & 23.9 \\
& $16-20$ years & 13.2 \\
& 21 - 25 years & 10.6 \\
& 26 - 30 years & 4.4 \\
& 31 years or more & 4.4 \\
& & 5.3 \\
\hline
\end{tabular}

Table IV: World Wide Web Site Characteristics

\begin{tabular}{|l|l|l|}
\hline Demographic & Frequency & Percentage \\
\hline Site Age & 32 & \\
6 months or less & 44 & 28.3 \\
$7-12$ months & 20 & 38.9 \\
13-18 months & 12 & 17.6 \\
19-24 months & 2 & 10.6 \\
25 - 32 months & 3 & 1.7 \\
33 months or longer & & 2.6 \\
\hline Website Usage & 84 & \\
Company Information & 77 & 69.4 \\
Product Information & 64 & 63.6 \\
Sales & 60 & 52.8 \\
Customer Information & 35 & 49.5 \\
Pricing Information & & 28.9 \\
\hline Website Developer & 58 & \\
In-house person & 28 & 51.3 \\
External consultant & 15 & 24.7 \\
In-house team & 12 & 13.2 \\
External Internet Provider & & 10.6 \\
\hline Website Content Maintainer & 67 & \\
In-house person & 18 & 59.2 \\
In-house team & 16 & 15.9 \\
External consultant & 12 & 14.1 \\
External Internet Provider &
\end{tabular}

\section{HYPOTHESIS TESTING}

Table V shows the results of testing each of the hypotheses derived above. Non-parametric statistical methods were used in the hypothesis testing process due to significant levels of skewness and kurtosis. Newbold (1991) argues that in circumstances where a significant number of observations are available, non-parametric statistical methods are approximately equal in predictive strength to their parametric counterparts. 
Table V: Summary of Hypothesis Test Results

\begin{tabular}{|c|l|c|c|c|}
\hline Hypothesis & \multicolumn{1}{|c|}{ Element } & Mann-Whitney U & Z Score & Significance \\
\hline $\mathrm{H}_{l a}$ & Website Use & 1296.00 & -1.007 & .314 \\
\hline $\mathrm{H}_{l b}$ & Number of PCs & 1182.00 & -1.677 & .094 \\
\hline $\mathrm{H}_{l c}$ & PCs per Employee & 1239.50 & -1.332 & .183 \\
\hline $\mathrm{H}_{l d}$ & Number of Applications & 1373.00 & -.536 & .592 \\
\hline $\mathrm{H}_{2 a}$ & Years of Computer use & 1416.00 & -.273 & .785 \\
\hline $\mathrm{H}_{2 b}$ & Years of Web Use & 1372.50 & -.314 & .754 \\
\hline
\end{tabular}

${ }^{a}$ Two Tailed significance

\section{RESULTS AND DISCUSSION}

Does a company's engagement of consultants or ISPs affect that company's use of their WWW site?

Analysis of the results found no significant relationship between the use of consultants and any of the research items. The hypothesis test results raise a number of interesting outcomes and these are worth exploring on a case by case basis.

The effect of consultants on web usage is integral to this study. The results found no significant difference between those companies that engaged consultants and those that did not. One possible explanation for this might be that consultants make no difference to the way in which commercial websites are used, however this is not necessarily the case. It is possible that had these businesses not engaged consultants, their websites would not have had as broad a range of uses. This finding is of substantial significance: the engagement of a consultant makes the site's use no more or less varied than those of other businesses who do not engage external expertise. Another interpretation of these findings is that, at this level of technological intervention, consultants do not have any significant impact on World Wide Web technology.

Second, the results suggest that businesses of any degree of experience are equally likely to engage consultants. This finding contrasts with evidence put forward by Toole et al. (1996), who found that firms that received some form of management assistance were generally younger and less experienced in their particular business environments. One explanation for this outcome may be that while some experienced businesses understand the technology and can implement it without risk, others can predict when they will need to rely on external knowledge. Inexperienced businesses may also know that they lack knowledge in a particular area, or they are wary of the introduction of new technology, hence the engagement of consultants. This argument would be consistent with Soh et al. (1992) and Turner (1982). A further explanation for this outcome concerns the political nature of consultant engagement as noted by Sturdy (1997a) and Bennett (1990), whereby consultants may be engaged by businesses not to assist in technology management but rather in order to defer or shift liability for project failure onto an external body, or to validate an existing or proposed course of action.

Third, the duration of system use also had no association with consultant engagement and use. Consultants had been engaged by businesses regardless of the number of years for which the business had been using computer or WWW technology. If firms with substantial computer system experience were enlisting consultant help with WWW technology adoption, then this suggests that perhaps firms view WWW technology as markedly different to other technologies. This finding would be consistent with Goode and Stevens (2000), who noted differences between World Wide Web technology and more traditional information systems.

If, as has been discussed earlier, the initial adoption is the most challenging and demanding aspect of the adoption process, it is possible that the consultants were not engaged in these projects for a long enough period of time. The finding that only $20 \%$ of respondents were continuing with their consultant engagement supports this conclusion, as does anecdotal evidence from the respondent group, a number of whom expressed dissatisfaction with their consultants. One respondent wrote, "If we'd had the choice again, we wouldn't have used [the consultant]...we'd have tried it ourselves". Another respondent, whose site had been designed by and was hosted with an ISP, wrote, "Our website is failing because of [our ISP]". This would not be the first instance of consultant debility or failure: Wilder (1987), Nadel (1988), Fincham (1999) have made similar observations. A number of respondents also expressed concern that the consultant had not transferred to the business the crucial knowledge they required to manage the website. This was evidenced in respondent anecdotal remarks, such as, "[The consultant] never told us what he was doing - it was a complete mystery". Apart from simple carelessness or lack of due attention, this may be because the consultant is hopeful for future engagement and is reluctant to surrender the intellectual assets that would bring this about. Alternatively, the consultant may be concerned about the ease with which their competitive advantage in this arena could be eroded. In this regard, Sturdy (1997a) notes, "it should be emphasised that consultants actively contribute to the conditions of their demand" and "[consultants] not only normalise problems, but elaborate them, and direct attention to new ones". Rassam and Oates (1991) make similar observations.

This findings in aggregate have implications for the ways in which businesses are using their websites. First, there appears to be a core group of site applications in common usage. These are the promotion of products and 
services, the provision of data and information and the processing of business transactions. This list, and that provided in the questionnaire may not have been exhaustive, however - businesses may have used their sites for other, more technically demanding applications, such as order tracking or wireless communication. While space was provided on the survey instrument for respondents to add their own applications, few made use of this feature. This issue merits further analysis.

An alternative interpretation of this finding is that consultants have more profound effects on the technical aspects of the website adoption project. It is possible that consultants are engaged not for their ability to supplement or augment site usage and content, but rather for their assistance in the site's physical implementation (server installation, for instance), or the site's coding (the implementation of more complex technology such as JavaScript, Flash or server-side scripting languages in addition to more basic HTML).

\section{CONCLUSIONS AND FURTHER RESEARCH}

This study has sought to contribute to the body of information system adoption research in general and WWW adoption in particular. The study is, however, subject to a number of limitations. It is possible that there are more site applications than those mentioned in the survey. Additionally, the study was conducted in an Australian context, and the degree to which the results are generalisable to other geographical areas is unknown. As with most studies involving survey methods, the research is open to self selection bias and this may distort the true facts. These limitations, whose overall effect is unknown, may mitigate the findings of the study.

It is important to understand that while no relationship is found between consultant engagement and website usage, the finding does not provide enough evidence to support the re-evaluation or disengagement of the consultant role. The finding does, in conjunction with respondent comments, however, suggest that the relationship between consultant engagement and website use deserves further research attention. The findings also suggest that deeper examination of the propositions tested here would be welcome. For instance, prior research has suggested that less experienced organisations may be more likely to engage consultants, however it would also make for interesting analysis to examine conditions of consultant engagement when firms exhibit substantial experience with information systems and consultants. It is possible that such firms may be more familiar with the pitfalls of consultant engagement, as expressed by some of the organisations in this study. Engagements in these circumstances may be more successful.

Finally, it should be noted that this study is of a purely exploratory nature and many factors still require examination. The range of website uses requires critical re-examination, as does the exact nature of the services offered by the consulting group. Due to the field's infancy, a case study approach may be the most scholarly rewarding approach for this. The large number of consulting groups in the marketplace, in addition to the frequency of their engagement suggests these firms must provide some tangible benefit to World Wide Web adopters. The finding of a lack of a relationship between the consultant's engagement and the variability of site application appears to contradict this. These areas provide fertile ground for further research.

\section{REFERENCES}

Abell, W., Lim, L. (1996) "Business Use of the Internet in New Zealand: An Exploratory Study", AusWeb 96

Bajaj, A., Nidumolu, S. R., (1998) “A Feedback Model to Understand Information System Usage”, Information \& Management, Vol. 33, No. 4, 25 March, 213-224

Bennett, R. (1990) Choosing and Using Management Consultants, Kogan Page Publishers, London

Bhimani, A. (1996) "Securing the Commercial Internet", Communications of the ACM, Vol. 39, No. 6, June, pp. $29-35$

Cavaye, A. L. M., Cragg, P., B. (1995) "Factors Contributing to the Success of Customer Oriented Interorganisational Systems", Journal of Strategic Information Systems, Vol. 4, No. 1, pp. 13 - 30

Church, A. (1993) "Estimating the Effect of Incentives on Mail Survey Response Rates: a Meta-Analysis", Public Opinion Quarterly, Vol. 57, No. 1, pp. 62 - 79

Delone, W. H. (1981) "Firm Size and the Characteristics of Computer Use", Management Information Systems Quarterly, December, pp. 65 - 77

Dillman, D. A. (1978) Mail and Telephone Surveys: The Total Design Method, John Wiley and Sons

Doll, W. J., Torkzadeh, G., (1998) "Developing a Multidimensional Measure of System-use in an Organizational Context”, Information \& Management, Vol. 33, No. 4, 25 March, 171-185

Dou, H., Dou, J., (1999), "Innovation Management Technology: Experimental Approach for Small Firms in a Deprived Environment”, International Journal of Information Management, Vol. 19, No. 5, October, 401-412

Dubin, R. (1978) Theory Building, Free Press, New York,.

Feher, A., Towell, E. (1997) "Business Use of the Internet", Internet Research: Electronic Networking Applications and Policy, Vol. 7, No. 3, pp. 195 - 200 
Filion, F. L. (1975) “Estimating Bias Due to Non-Response in Mail Surveys”, Public Opinion Quarterly, Fall, pp. $482-492$

Fincham, R. (1999) "The Consultant-Client Relationship: Critical Perspectives on the Management of Organisational Change", Journal of Management Studies, Col. 36, No. 3, pp. 335 - 352

Fitzgerald, J. (1975) "In-house Staff Versus Outside Consultants", Proceedings of Academy of Management, August, pp. 113 - 115

Gable, G. G. (1991) “Consultant Engagement for Computer system Selection”, Information \& Management, 20 , pp. $83-93$

Gallaugher, J. (1999) "Challenging the New Conventional Wisdom of Net Commerce Strategies", Communications of the ACM, July, pp. 27-29

Goode, S., Stevens, K. (2000) "An Analysis of the Business Characteristics of Adopters and Non-adopters of World Wide Web Technology”, Journal of Information Technology and Management, Vol. 1, No. 1, pp. $129-154$

Grover, V., Lee, C., Durand, D. (1994) “Analysing Methodological Rigor of MIS Survey Research from 1980 1989”, Information \& Management, Vol. 24, pp. 305 - 318

Haynes, P. J., Becherer, R. C., Helms, M. M. (1998) "Small and Mid-Sized Businesses and Internet Use: Unrealized Potential?" Internet Research: Electronic Networking Applications and Policy, Vol. 8, No. 3, pp. $239-235$

Jarvenpaa, A. L., Ives, B. (1996) "Introducing Transformational Technologies - The Case of Web Technology", International Journal of Electronic Commerce, Vol. 1, No. 1, Fall, pp. 95 - 126

Jarvenpaa, S. L., Todd, P. A. (1997) "Consumer Reactions to Electronic Shopping on the World Wide Web", International Journal of Electronic Commerce, Vol. 1, No. 2, pp. 59 - 88

Kole, M. A. (1983) “Going Outside for MIS Implementation”, Information \& Management, 6, pp. 261 - 268

Koreto, R. J. (1997) "When the Bottom Line is Online”, Journal of Accountancy, March, pp. 63 - 65

Lee, R. M. (1999) “Distributed Electronic Trade Scenarios: Representation, Design, Prototyping”, International Journal of Electronic Commerce, Vol. 3, No. 2, pp. 105 - 135

Lewis, T. (1996) “Alice in Wired World: Wonderland or Wasteland?”, Computer, July, pp. 17 - 19

Liang, T., Lai, H., (2002) "Effect of Store Design on Consumer Purchases: an Empirical Study of On-line Bookstores”, Information \& Management, Vol. 39, No. 6, May, 431-444

Lin, B. (1996) "Managing in an Information Highway Age: Critical Issues", Internet Research: Electronic Networking Applications and Policy, Vol. 6, No. 4, pp. $44-47$

Lindemann, M. A., Schmid, B. F. (1999) "Framework for Specifying, Building and Operating Electronic Markets", International Journal of Electronic Commerce, Vol. 3, No. 2, pp. 7 - 21

Liu C., Arnett, K. P., Capella, L. M., Beatty, R. C. (1997) "Web sites of the Fortune 500 Companies: Facing Customers Through Home Pages", Information \& Management, Vol. 31, pp. 335 - 345

Major, M. J. (1999) “After the Merger: Easing the Transition”, TMA Journal, Vol. 19, No. 5, pp. 54 - 57

Malhotra, M. K., Grover, V. (1998), "An Assessment of Survey Research in POM: From Constructs to Theory”, Journal of Operations Management, 16, 4, July, 407-425.

McLennan, S. (1999), Yearbook Australia, Australian Bureau of Statistics, Government Publishing Service, Canberra

Montazemi, A. R. (1988) "Factors Affecting Information Satisfaction in the Context of the Small Business Environment”, MIS Quarterly, June, pp. 239 - 256

Nadel, R. B. (1988) “Computer Consulting for the Smaller Firm: Opportunity or Trap?” CPA Journal, Vol. 58, No. 4, pp. $18-29$

Nahavandi, A., Chesteen, S. (1988) “The Impact of Consulting on Small Business: A Further Examination”, Entrepreneurship Theory and Practice, Fall, pp. $29-40$

Nambisan, S., Wang, Y. (1999) “Roadblocks to Web Technology Adoption?", Communications of the ACM, Vol. 42, No. 1, January, pp. 98 - 101

Newbold, P. (1991), Statistics for Business and Economics, 3rd Edition, Prentice-Hall International, New Jersey

O'Connor, M., Bentley, J., Calvert, C. (1997) "Small Business and the Internet”, 8th Australasian Conference on Information Systems

Palvia, P. C., Palvia, S. C., (1999) “An Examination of the IT Satisfaction of Small-Business Users", Information \& Management, Vol. 35, No. 3, 8 March, 127-137

Panurach, P. (1996) "Money in Electronic Commerce: Digital Cash, Electronic Fund Transfer and E-cash", Communications of the ACM, Vol. 39, No. 6, June, pp. 45 - 51

Ranganathan, C., Ganapathy, S., (2002) "Key Dimensions of Business-to-Consumer Web Sites”, Information \& Management, Vol. 39, No. 6, May, 457-465

Rassam, C., Oates, D. (1991), Management Consultancy - The Inside Story, Mercury Publishers, London

Ravindran, S., Barua, A., Lee, B., Whinston, A. B. (1996) "Strategies for Smart Shopping in Cyberspace”, 
Journal of Organisational Computing and Electronic Commerce, Vol. 6, No. 1, pp. 33-49

Soh, C. P. P., Yap, C. S., Raman, K. S. (1992) "Impact of Consultants on Computerisation Success in Small Business", Information \& Management, Vol. 22, pp. 309 - 319

Spiller, P., Lohse, G. L. (1998) “A Classification of Internet Retail Stores", International Journal of Electronic Commerce, Vol. 2, No. 2, Winter, pp. 29 - 56

Sturdy, A. (1997) "The Dialectics of Consultancy", Critical Perspectives on Accounting, Vol. 8, pp. 511 - 535

Sturdy, A. (1997a) "The Consultancy Process: An Insecure Business?”, Journal of Management Studies, Vol. 34, No. 2, pp. $389-413$

Swatman, P. M. C., Poon, S., Green, D. G., Payne, P. (1995) "Overtaking on the Information Superhighway: Strategic Use of the Internet", Australian Conference on Information Systems

Tan, M., Teo, T. S. H. (1998) "Factors Influencing the Adoption of the Internet", International Journal of Electronic Commerce, Vol. 2, No. 3, Spring, pp. 5 - 18

Teo, T. S. H., Tan, M., Buk, W. K. (1998) "A Contingency Model of Internet Adoption in Singapore" International Journal of Electronic Commerce, Vol. 2, No. 2, , pp. 95 - 118

Tisdall, P. (1982), Agents of Change - The Development and Practice of Management Consultancy, Heinemann Publishing, London

Toole, H. R., Sciglimpaglia, D., Brkovic, N. (1996) "Interest in the Use of Consulting Services by Small Business: A Comparison of Gender and Ethnicity", Proceedings of the International Council on Small Business

Turner, J. S. (1982) "Firm Size, Performance and Computer Use", Proceedings of the Third International Conference on Information Systems, December

Walsham, G. (1993) Interpreting Information Systems in Organisations, Wiley Publishing, Chichester, UK

Warkentin, M. E. (1995) "Competitive Advantage on the World Wide Web: A Webmaster's Guide", Applied Computing Review, Vol. 3, No. 2, pp. 25 - 32

Wilder, C. (1987) "Systems Integrators", Computer World, December 